\title{
Response of small mammals and birds to partial cutting and clearcutting in northwest British Columbia
}

\author{
by J.D. Steventon ${ }^{1}$, K.L. MacKenzie ${ }^{2}$ and T.E. Mahon ${ }^{3}$
}

A challenge facing forest managers is providing habitats for wildlife associated with mature or old-growth forests. One approach is to use partial cutting which maintains forest cover while still allowing timber harvest. We compared small mammal (voles, mice and shrews) and bird abundance after two intensities of partial cutting (30\% and $60 \%$ volume removal) to clearcuts and uncut natural stands in coast-interior transitional forests of British Columbia. The $30 \%$ removal resulted in no significant difference in the bird community compared to the uncut stands, while southern red-backed voles (Clethrionomys gapperi) increased in abundance. Bird and small mammal communities in the $60 \%$ removal treatment were closer to the uncut forest than to clearcuts, but also included species typical of clearcuts. At least one bird species, Yellowrumped Warbler (Dendroica coronata), was most abundant in the $60 \%$ removal treatment. Several species such as the meadow vole (Microtus pennsylvanicus) and Dark-eyed Junco (Junco hyemalis) were most abundant in clearcuts, and Lincoln's Sparrow (Melospiza lincolnii) and Chipping Sparrow (Spizella passerina) were almost exclusively found in clearcuts. Scattered aspen and birch trees left in two of the clearcuts were used as cavity nest trees by Red-breasted Sapsuckers (Sphyrapicus ruber), Hairy Woodpeckers (Picoides villosus), and Tree Swallows (Tachycineta bicolor). We concluded that both of the partial cutting treatments provided habitat for small mammals and birds typical of mature forest, although the heavy removal began to show a shift towards species typical of clearcuts. Because no single treatment was optimal for all species, we recommend that partial cutting be part of a landscape strategy to provide a range of habitat conditions similar to those occurring under natural disturbance regimes.

Key words: Partial cutting, clearcutting, silvicultural systems, wildlife habitat, biodiversity, ecosystem management, birds, small mammals
L'élaboration d'habitats associés aux forêts matures ou aux vieilles forêts constitue un défi auquel font face les aménagistes forestiers. Une approche repose sur l'utilisation de la coupe partielle qui permet de maintenir le couvert forestier tout en récoltant de la matière ligneuse. Nous avons comparé l'abondance des petits mammifères (campagnols, souris et musaraignes) et des oiseaux après des coupes partielles effectuées selon deux intensités (coupe de $30 \%$ et de $60 \%$ du volume) à des coupes à blanc et des peuplements naturels non perturbés parmi les forêts transitionnelles entre la côte et l'intérieur de la Colombie-Britannique. La coupe de $30 \%$ n'a pas entraîné de différence significative au sein de la communauté ailée par rapport aux peuplements non perturbés, tandis que les populations de campagnol à dos roux (Clethrionomys gapperi) ont augmenté en abondance. Les communautés d'oiseaux et de petits mammifères étudiées sous le traitement de $60 \%$ de coupe se comparaient plus étroitement aux communautés issues des forêts non perturbées qu'à celles des coupes à blanc, mais comprenaient également des espèces typiques des coupes à blanc. Au moins une des espèces d'oiseaux, la paruline à croupion jaune (Dendroica pennsylvanicus), était plus abondante dans les coupes à $60 \%$. Certaines espèces comme le campagnol des champs (Microtus pennsylvanicus) et le junco ardoisé (i) étaient plus abondantes dans les coupes à blanc, alors que le bruant de Lincoln (Melospiza lincolnii) et le bruant familier (Spizella passerina) se retrouvaient exclusivement dans les coupes à blanc. Les quelques peupliers et bouleaux laissés dans deux des coupes à blanc furent utilisés par les oiseaux nicheurs dans des cavités, soit le pic à poitrine rouge (Sphyrapicus ruber), le pic chevelu (Picoides villosus) et l'hirondelle bicolore (Tachycineta bicolor). Nous concluons que les deux coupes partielles procurent un habitat aux petits mammiferes et oiseaux semblables à ce qu'on retrouve en forêt mature, même si la coupe plus intense tend à indiquer un changement vers des espèces typiques des coupes à blanc. Comme aucun traitement n'a été le meilleur pour toutes les espèces, nous recommandons que la coupe partielle soit un élément de l'aménagement des paysages constituant un éventail de conditions se rapportant à l'habitat semblable à ce qu'on retrouve suite à des régimes de perturbation naturelle.

Mots clés: coupe partielle, coupe à blanc, modes sylvicoles, habitat faunique, biodiversité, aménagement écosystémique, oiseaux, petits mammifères

\section{Introduction}

Clearcutting has been the dominant silvicultural system in British Columbia, accounting for $90 \%$ of the area harvested from 1984 to 1994 (Government of BC 1994). To help

\footnotetext{
${ }^{1}$ British Columbia Ministry of Forests, Bag 5000, Smithers, B.C., Canada V0J 2N0 ${ }^{2}$ Faculty of Forestry, University of British Columbia, Vancouver, B.C. Present address: Weldwood Canada Ltd., Box 97, 100 Mile House, B.C., Canada VOK 2E0

${ }^{3}$ Department of Biological Sciences, Simon Fraser University, Burnaby, B.C. Present address: WildFor Consultants, Box 2962, Smithers, B.C., Canada VOJ 2NO
}

achieve non-timber objectives, management agencies are now considering wider application of partial cutting systems (Government of BC 1995a). One of the perceived values of partial cutting is the maintenance of wildlife habitat.

Managed landscapes generally have less mature and oldgrowth forest habitat than natural landscapes (Government of BC 1995b). Partial cutting, including uneven-aged and shelterwood silvicultural systems as well as commercial thinning, is one approach suggested for conserving wildlife associated with mature and old-growth forests (McComb et al. 1993, Thompson et al. 1993, Buongiorno et al. 1994). Other approaches include designating protected areas; retaining some trees within clearcuts to achieve greater structural sim- 
ilarity to old-growth within commercial rotations; and the lengthening of rotations (Hunter 1990, Spies et al. 1991, Thompson et al. 1993, Coates and Steventon 1995, Hansen et al. 1995a). From a timber production perspective, partial cutting is more complex and costly to apply than clearcutting (McComb et al. 1993, Thibodeau et al. 1996) but may allow access to areas that otherwise would be reserved from harvesting.

We examined the initial response of small mammals (voles, mice and shrews) and birds to two intensities of partial cutting, compared to clearcuts and uncut stands. This project is part of a larger multi-disciplinary study of partial cutting as an ecosystem management technique (Coates et al. 1997).

\section{Study Area}

The study area was the 4,000 ha Date Creek research site $\left(55^{\circ} 22^{\prime} \mathrm{N}, 127^{\circ} 50^{\prime} \mathrm{W}\right)$ near Hazelton, British Columbia. The forests were typical of the Interior Cedar-Hemlock, Moist Cold biogeoclimatic subzone ( $\mathrm{ICHmc}$ ) that are transitional between the Coastal Western Hemlock zone and the interior SubBoreal Spruce zone (Meidinger and Pojar 1991). The stands that we studied were dominated by western hemlock (Tsuga heterophylla), with lesser amounts of hybrid spruce (the complex of white spruce (Picea glauca), Sitka spruce (Picea sitchensis), and occasionally Engelmann spruce (Picea engelmannii)), lodgepole pine (Pinus contorta), western redcedar (Thuja plicata), subalpine fir (Abies lasiocarpa), amabilis fir (Abies amabilis), paper birch (Betula papyrifera), trembling aspen (Populus tremuloides), and black cottonwood (Populus balsamifera).

The study area was dominated $(72 \%)$ by mature $(\geq 100$ years) and old-growth forest ( $\geq 200$ years). The dominant large-scale stand-initiating disturbance in ICHmc forests in the past has been wildfire, with a mean return interval of approximately 200 years (Government of BC 1995b). Root rot, insect attack, windthrow, and other smaller-scale processes shaped these forests between fire events. With age, the stands became increasingly dominated by western hemlock with minor components of redcedar, fir, spruce and cottonwood (LePage 1995).

Partial cutting is considered feasible in the ICHmc because of the prevalence of shade tolerant western hemlock with good natural regeneration potential (Weetman et al. 1990), and as a way of mimicking natural gap creation disturbances common in these forests. Openings as small as 0.2 ha are adequate for regenerating even the light-demanding species such as aspen and lodgepole pine (K.D. Coates, unpublished data, BC Ministry of Forests, Smithers, B.C.). This provides considerable flexibility in designing a silvicultural regime that can successfully regenerate the forest while managing for other forest values (Bradshaw 1992).

\section{Treatments and Study Methods}

We applied two intensities of partial cutting during one harvest entry for comparison to uncut forests (UC) and clearcuts (CC). The light removal treatment (LRT) harvested approximately $30 \%$ of the stand volume as single stems and small groups (analogous to single tree and group selection systems). The heavy removal treatment (HRT) harvested about $60 \%$ of the stand volume; $30 \%$ in openings of $0.1-0.5$ ha and $30 \%$ by single stem thinning between openings (analogous to an irregular shelterwood system). Two of the clearcut treatment units contained scattered mature trees, mostly aspens and birches. There

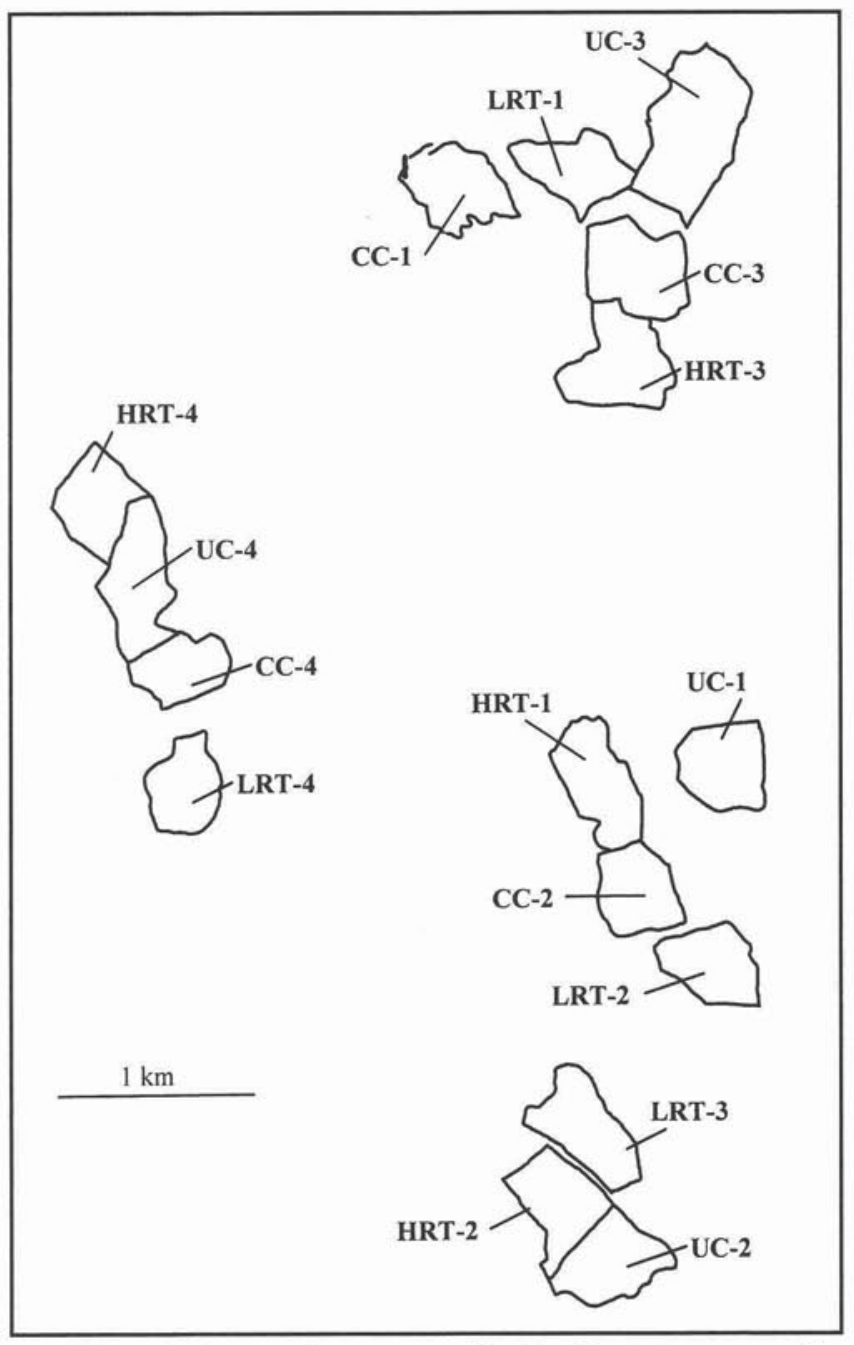

Fig. 1. Spatial layout of treatment units. Number represents statistical blocking factor: 1 = mesic - submesic, 135 years; 2 = mesic, 135 years; 3 = mesic - subhygric, 135 years;

$4=$ mesic, 350 years.

were four replicates (Fig. 1) of each of the four treatments (16 units total) applied in a randomized block design. The blocking factors were ecological site type and age of forest (mesic 135 years; mesic - submesic 135 years; mesic-subhygric 135 years; mesic 350 years). We randomly assigned the four treatments to the treatment units within each block. Treatment units averaged $20 \mathrm{ha}$, and logging was conducted during the summer and fall of 1992 and winter of 1992-93 (Coates et al. 1997).

To characterize the treatments, we measured the area in canopy openings $\geq 5 \mathrm{~m}$ in width; basal area/ha and $\mathrm{dbh}$ distribution of live and dead trees; and volume/ha and diameter distribution of downed logs in each treatment unit. These features are important habitat attributes for a variety of forest fauna (Harmon et al. 1986, Hunter 1990, Bradshaw 1992, Sammuelsson et al. 1994). The area in canopy openings was digitized from 1:5000 scale air photos; basal area was measured by prism $(\mathrm{N}$ $=43$ for each UC and LRT treatment unit, $\mathrm{N}=50$ for HRT units); and volume of logs by the line intercept method (Van Wagner 1982) using $90 \mathrm{~m}$ intercept lines in an equilateral triangle of 


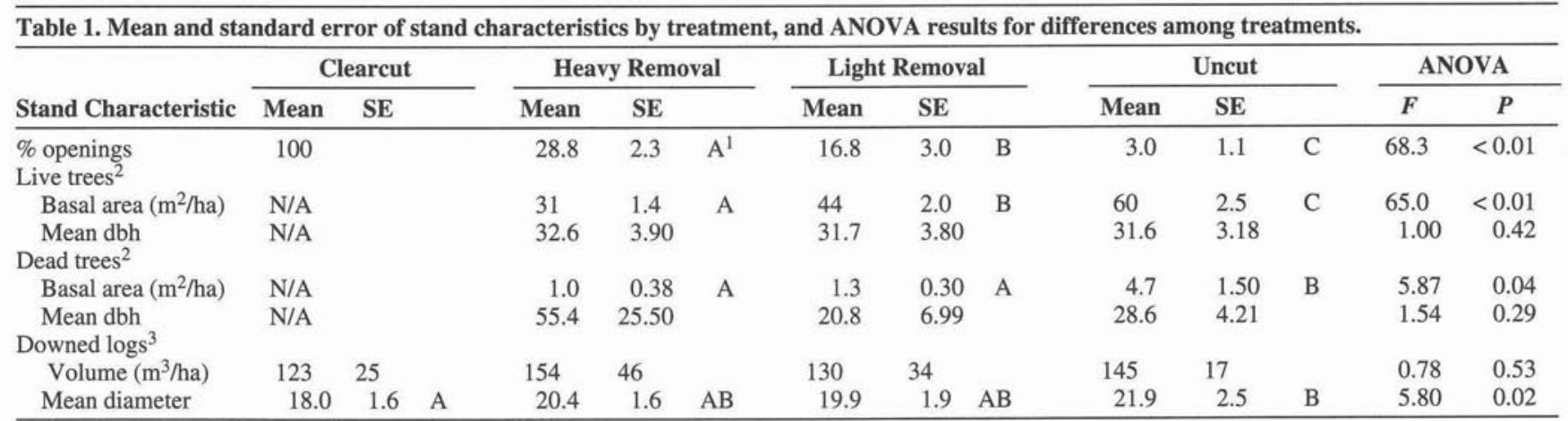

${ }^{1}$ The same letter indicates no significant difference between treatments (Tukey test $P \geq 0.10$ ).

${ }^{2}$ Trees $\geq 17.5 \mathrm{~cm}$ dbh.

${ }^{3} \mathrm{Logs} \geq 10 \mathrm{~cm}$ diameter at point of interception.

$30 \mathrm{~m}$ per side (10 randomly placed intercept lines per treatment unit).

We measured small mammal abundance from May through September in 1993 and 1994 by repeated live-trapping with mark and release on 2 ha grids $(7 \times 7$ trap array), approximately centred in each treatment unit. Each treatment unit was sampled bi-weekly in 1993, and every three weeks in 1994. Within each year, we used the total number of individual animals captured as an index of relative abundance, and recapture rate (proportion of individuals captured in at least two trapping sessions) as an index of survival or proportion of transient animals in the population. Shrews did not usually survive in the traps, thus the data represents a removal sample for that group.

We surveyed relative abundance of birds using the spot mapping technique. Each treatment unit was surveyed nine times from May through July during one season pre-treatment (1992), and during two seasons post-treatment (1993 and 1994). Observers systematically walked through each treatment unit in early morning and recorded all birds heard or seen on 1:5000 scale stand maps. To ensure even coverage and to facilitate mapping of bird locations, flagged lines with a $50 \mathrm{~m}$ spacing were established through each unit. For each survey, every second line was walked, and observers and lines were alternated between surveys. Relative abundance of each bird species was calculated as the mean number of detections $/ 20$ ha for the nine surveys in each year. We excluded observations recorded on the spot-map as repeated observations of the same bird on that survey.

Along with individual species abundance, we compared bird community similarity among treatments using the Renkonen Percent Similarity Index (Renkonen 1938, cited in Krebs 1989). If both communities have exactly the same species in the same abundance then percent similarity $=100$, if none of the species are the same then percent similarity $=0$.

The treatment effect probabilities are based on the randomized block ANOVA design, with cutting treatment considered a fixed factor, and ecological block a random factor $(F=$ treatment mean square / treatment $\times$ block interaction mean square). To determine if combining years was justified, we tested for a year $\times$ treatment interaction $(F=$ year $\times$ treatment mean square $/$ residual error mean square). Statistical power of the ANOVA is presented as the minimum difference between treatment means that could have been detected with $80 \%$ power at alpha $=0.10$, expressed as a range (Bergerud 1995). Differences greater than the upper value of the range would almost certainly have been detected with $80 \%$ power, differences less than the lower value would not have been detected, and differences within the range potentially had sufficient power to be detected.

For ANOVA's with a significant treatment effect, post-hoc pairwise comparisons between treatments used the Tukey test with an experiment-wide threshold for significance of $P$ $\leq 0.10$. We chose a threshold alpha of 0.1 rather then the traditional 0.05 to avoid being overly conservative for individual comparisons between two treatments. Thus the probability of a type I error (concluding a significant difference when there is none) is $\leq 0.10$ for 5 comparisons simultaneously, and $\leq 0.02$ for any individual comparison.

\section{Results}

\section{Stand Structure}

The four treatments differed primarily in tree basal area and proportion of area in canopy openings (Table 1). The LRT remained as a mature forest environment in appearance, while the HRT was clearly a modified environment with distinct openings. The proportional reduction of standing dead trees was greater than for live trees, and was of the same magnitude for both LRT and HRT because of snag removal for worker safety. The mean diameter of both live and dead trees, and volume of downed logs, did not differ significantly by treatment, while the mean diameter of downed logs in clearcut and uncut treatments were statistically different.

\section{Small Mammals}

The small mammal fauna of the area was dominated by five species: southern red-backed vole (Clethrionomys gapperi), meadow vole (Microtus pennsylvanicus), deer mouse (Peromyscus maniculatus), common shrew (Sorex cinereus), and dusky shrew (Sorex monticolus). Water shrew (Sorex palustris), long-tailed vole (Microtus longicaudus), and pygmy shrew (Sorex hoyi) occurred on the study area but were captured infrequently $(n<10)$. We are uncertain of species identification of the common and dusky shrews by some observers, hence we report them as Sorex spp.

Differences in abundance among treatments resulted primarily from summer population growth (Fig. 2), rather than differences in abundance at the start of trapping in spring. There was a significant year by treatment interaction in relative abundance 


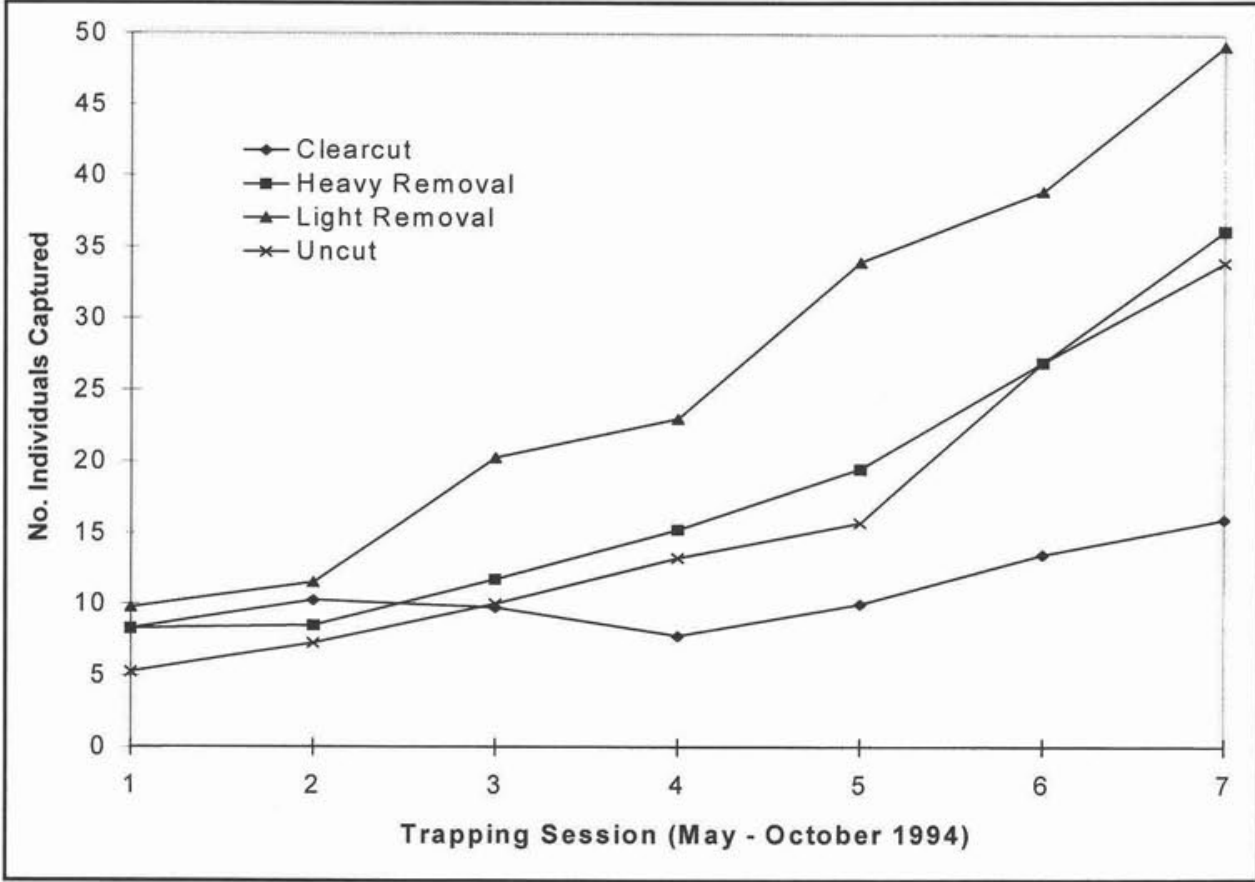

Fig. 2. Mean number of individual red-backed voles captured by treatment $(n=4)$ and trapping session in 1994. The trapping effort (no. trap nights) is equal for all data points. of red-backed voles $(P=0.02)$, meadow voles $(P<0.01)$, and marginally for deer mice $(P=0.11)$, thus we analyzed each year separately (Fig. 3). There was no year by treatment interaction for shrews $(P=0.79)$. In 1993 , red-backed vole was the only species significantly different among treatments (Table 2). While the red-backed vole was the most abundant species in all treatments, it was significantly more abundant in the LRT than UC. The other species did not show significant differences by treatment, but the few meadow voles captured in 1993 were all in clearcuts.

In 1994, there was a substantial increase in abundance of deer mice and meadow voles in the study area, and all species except the shrews differed significantly in abundance by treatment (Fig. 3, Table 2). Red-backed voles were most abundant in the LRT, followed by the UC and HRT, and least abundant in CC. Deer mice were significantly more abundant in CC than UC. Meadow voles were more abundant in CC than in all other treatments.

Recapture rate for red-backed voles did not differ significantly (Fig. 4) by treatment ( $P=0.73, F=0.45)$. Deer mice differed in recapture rate by treatment $(P=0.03, F=5.50)$, with higher rates in CC and the HRT than in the LRT or UC treatments. There was no difference in recapture rate of meadow voles by treatment $(P=0.72, F=0.34)$, with the UC excluded from the analysis due to very few captures.

\section{Birds}

We detected 74 species of birds (Appendix 1), of which 34 were used in analyses (Table 3, Fig. 5). The remaining species were considered incidental (averaged less than 1 detection per survey); were usually detected in highly mobile flocks (e.g., crossbills and siskins); or were flying over the treatments (e.g., Common Loon, scientific names are provided in the appendix).

For all species except the Yellow-rumped Warbler, we found little evidence $(P>0.10)$ of pre-treatment differences in abundance among treatments. The Yellow-rumped Warbler had a greater mean pre-treatment abundance in the units that were later clear-cut $(P=0.05, F=3.713)$. There was also little statistical evidence that post-treatment responses differed by year (year $\times$ treatment interaction, $P>0.10$ ), except for the American robin, Yellow-rumped Warbler and Red-breasted Nuthatch. Thus we combined species abundance data for the two years. For the American Robin and Yellow-rumped Warbler, the pattern of treatment use was consistent between years but the magnitude of difference varied. The Red-breasted Nuthatch was most abundant in the HRT in 1993, but showed little difference between the HRT and LRT in 1994.

The community similarity (Renkonen Index) to UC of the LRT, HRT and CC (Fig. 5) differed significantly $(P<0.01$, $F=115.4)$. The community similarity to CC of the HRT, LRT and UC were not significantly different $(P=0.12, F=3.08)$. Both LRT and HRT were more similar to UC $(75 \%$ and $66 \%$ respectively) than to $\mathrm{CC}$. The treatment comparison with the least community similarity (31\%) was UC to CC. Pre-treatment similarity between treatment units within experimental blocks averaged $76 \%$ (range $71-80 \%$ ).

Many bird species differed in number of detections by treatment (Fig. 5), but for most species the statistical power for testing those differences was low because of limited sample size. The minimum detectable differences in abundance for many species (Table 3 ) were considerably greater than the observed differences in abundance (Appendix 1).

There were several species (e.g., Chestnut-backed Chickadee and Winter Wren) with low abundance in clearcuts, but no clear preference among the partial cuts or uncut forest. We detected Pacific-slope Flycatcher, Golden-crowned Kinglet, Swainson's Thrush, and Townsend's Warbler more often in UC than in LRT or HRT, but the differences were not statistically significant.

We detected Yellow-rumped Warblers significantly more often in the HRT than other treatments. The Three-toed 
1993

- Red-backed Vole $\mathbf{D}$ Deer Mouse 四Meadow Vole 目Shrew s

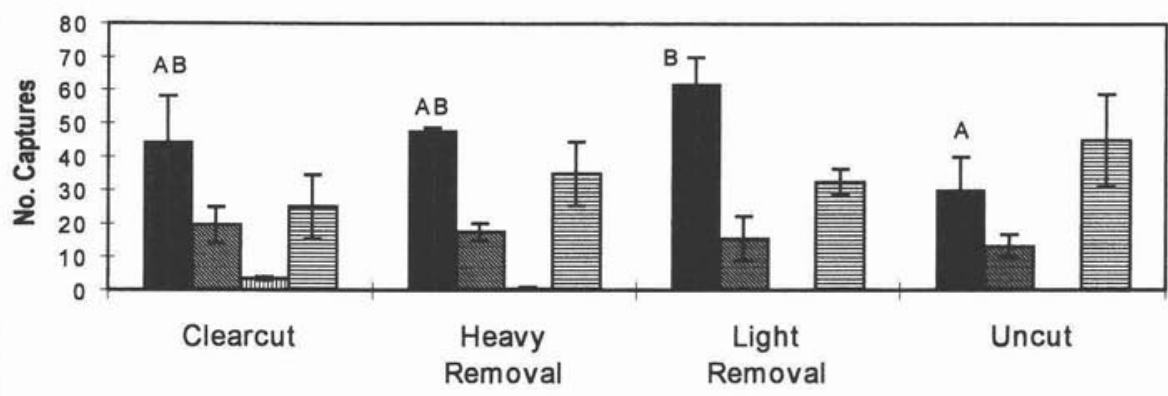

1994

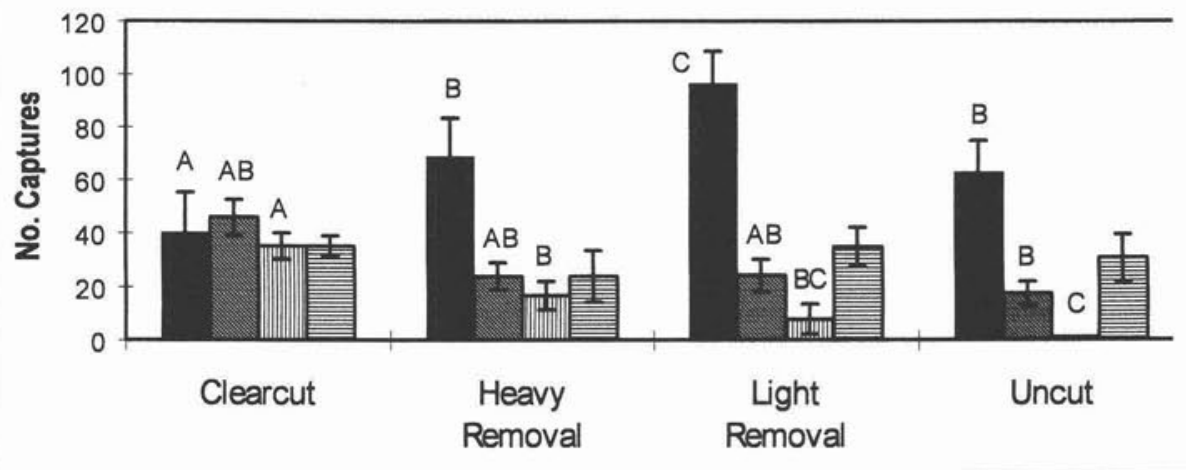

Fig. 3. Mean $( \pm S E)$ of number of individual small mammals captured by year and treatment. For species with a significant treatment effect (ANOVA $P \leq 0.10$ ), the same letter above the bar indicates no statistical difference between those treatments for that species (Tukey Test $P \geq 0.10$ ). Trapping effort (no. trap nights) was equal for all treatments.

Table 2. Results of ANOVA for treatment differences in small mammal abundance, and minimum significant difference (MSD) for Tukey Test. Minimum detectable differences for the ANOVA are for a power of $80 \%$ at alpha $=\mathbf{0 . 1 0}$. Units for ANOVA detectable difference and Tukey MSD are mean number of individuals captured

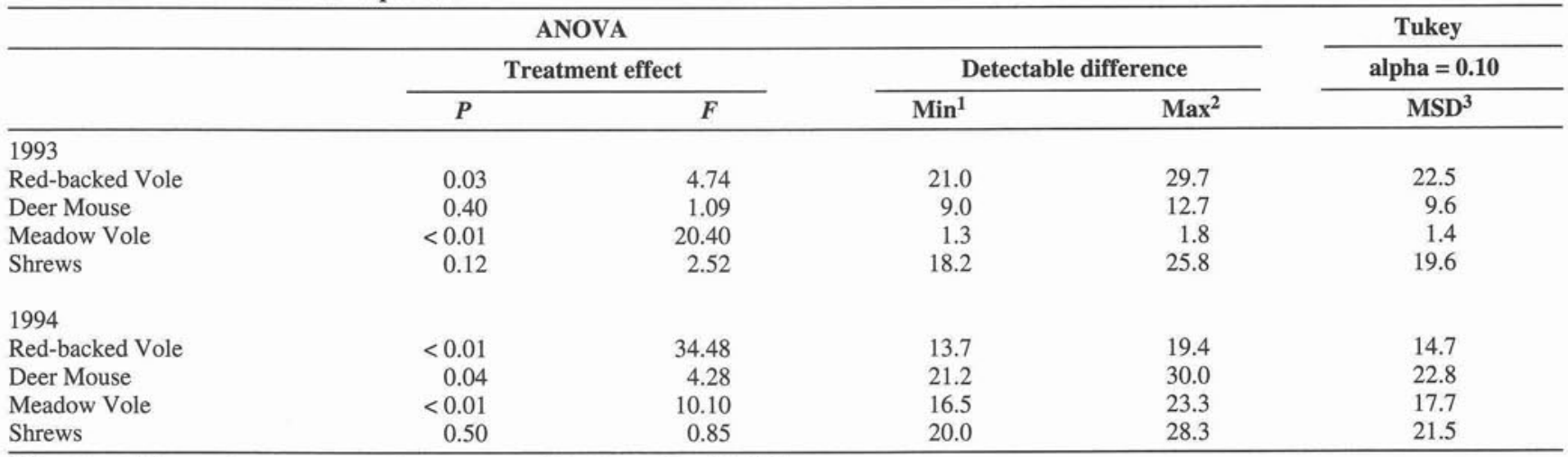

1. Smallest difference between means that was potentially detectable with $80 \%$ power.

2. Smallest difference between means that would almost certainly have been detected with $80 \%$ power.

3. Minimum difference between means that would be significant at $P \leq 0.10$.

Woodpecker, Red-breasted Nuthatch, Wilson's Warbler, Brown Creeper, Evening Grosbeak and Hammond's Flycatcher were detected most frequently in either the LRT or HRT, but the differences were not statistically significant.

American Robin and Dark-eyed Junco, while common in all treatments, were significantly more abundant in clearcuts, and the Lincoln's Sparrow and Chipping Sparrow were detected almost exclusively in clearcuts. Red-breasted
Sapsuckers and Hairy Woodpeckers were frequently detected in two of the clearcuts, where they nested in cavities of unharvested aspen trees but foraged in adjacent mature forest. They did not use the other two clearcuts which lacked residual trees. Tree Swallows foraged in clearcuts and nested in cavities of aspen trees within or adjacent to the clearcuts, and were rarely detected in the uncut forest. 


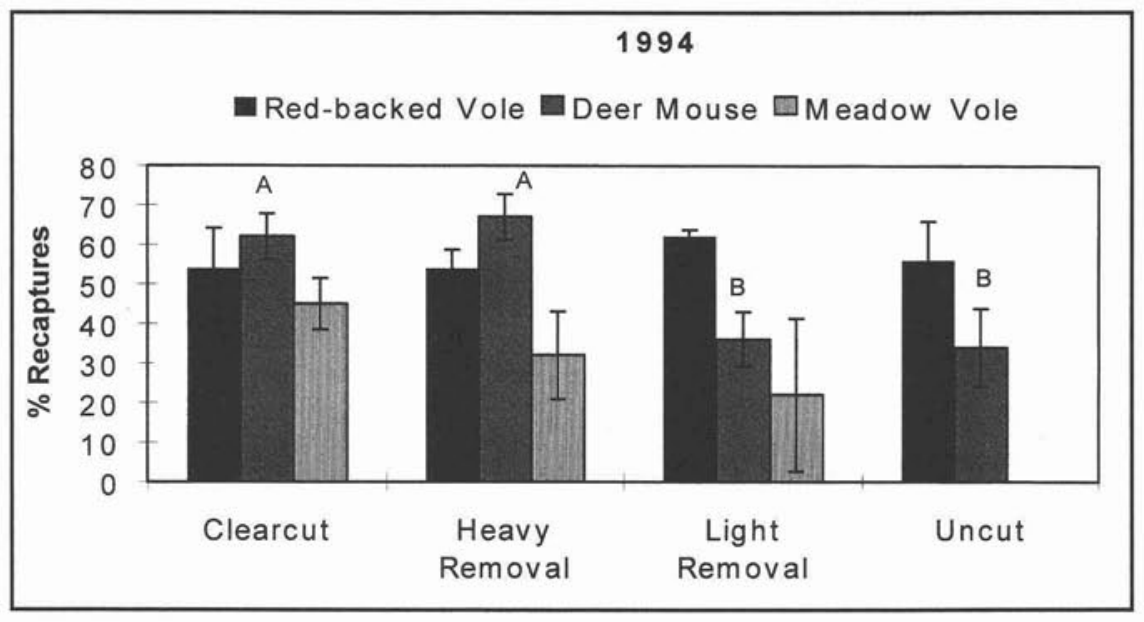

Fig. 4. Mean $( \pm$ SE) of \% of individual small mammals recaptured at least once in 1994 by treatment. For species with a significant treatment effect (ANOVA $P \leq 0.10$ ), the same letter above the bar indicates no statistical difference between those treatments for that species (Tukey Test $P \geq 0.10$ ).

Table 3. Results of ANOVA for treatment differences in relative bird abundance, and Minimum Significant Difference for Tukey's multiple comparison test. Units for ANOVA detectable difference and Tukey MSD are mean number of detections/20 ha

\begin{tabular}{|c|c|c|c|c|c|}
\hline \multirow[b]{3}{*}{ Species } & \multicolumn{2}{|c|}{ ANOVA } & & & \multirow{2}{*}{$\begin{array}{c}\text { Tukey } \\
\text { alpha }=\mathbf{0 . 1 0}\end{array}$} \\
\hline & \multicolumn{2}{|c|}{ Treatment effect } & \multicolumn{2}{|c|}{ Detectable difference } & \\
\hline & $P$ & $\boldsymbol{F}$ & $\operatorname{Min}^{1}$ & $\operatorname{Max}^{2}$ & MSD $^{3}$ \\
\hline American Robin & 0.01 & 6.13 & 10.5 & 14.9 & 11.3 \\
\hline Brown Creeper & 0.15 & 2.23 & 6.2 & 8.7 & 6.6 \\
\hline Chestnut-backed Chickadee & $<0.01$ & 21.77 & 9.9 & 14.0 & 10.6 \\
\hline Chipping Sparrow & $<0.01$ & 7.34 & 1.8 & 2.5 & 1.9 \\
\hline Common Raven & 0.36 & 1.21 & 0.9 & 1.2 & 0.9 \\
\hline Dark-eyed Junco & $<0.01$ & 81.57 & 11.3 & 16.0 & 12.1 \\
\hline Evening Grosbeak & 0.55 & 0.76 & 4.8 & 6.7 & 5.1 \\
\hline Golden-crowned Kinglet & 0.01 & 6.18 & 12.5 & 17.6 & 13.4 \\
\hline Gray Jay & 0.56 & 0.73 & 2.2 & 3.0 & 2.3 \\
\hline Hairy Woodpecker & 0.09 & 3.01 & 5.2 & 7.4 & 5.6 \\
\hline Hammond's Flycatcher & 0.38 & 1.17 & 24.1 & 34.1 & 25.9 \\
\hline Hermit Thrush & 0.02 & 5.86 & 8.5 & 12.0 & 9.1 \\
\hline Lincoln's Sparrow & 0.08 & 3.17 & 3.3 & 4.6 & 3.5 \\
\hline Magnolia Warbler & 0.33 & 1.32 & 0.9 & 1.3 & 1.0 \\
\hline MacGillivray's Warbler & 0.48 & 0.88 & 2.1 & 3.0 & 2.3 \\
\hline Northern Waterthrush & 0.75 & 0.40 & 2.5 & 3.5 & 2.7 \\
\hline Pacific-slope Flycatcher & $<0.01$ & 13.58 & 17.3 & 24.5 & 18.6 \\
\hline Red-breasted Nuthatch & 0.18 & 2.02 & 5.3 & 7.5 & 5.7 \\
\hline Red-breasted Sapsucker & 0.49 & 0.86 & 7.9 & 11.1 & 8.5 \\
\hline Ruby-crowned Kinglet & 0.23 & 1.73 & 1.5 & 2.1 & 1.6 \\
\hline Solitary Vireo & 0.69 & 0.50 & 1.7 & 2.4 & 1.8 \\
\hline Stellar's Jay & 0.42 & 1.05 & 4.3 & 6.2 & 4.7 \\
\hline Swainson's Thrush & 0.18 & 2.00 & 4.7 & 6.6 & 5.0 \\
\hline Three-toed Woodpecker & 0.01 & 6.56 & 4.1 & 5.7 & 4.4 \\
\hline Townsend's Warbler & $<0.01$ & 15.64 & 23.9 & 33.9 & 25.7 \\
\hline Tree Swallow & 0.07 & 3.36 & 2.2 & 3.1 & 2.3 \\
\hline Varied Thrush & $<0.01$ & 8.72 & 7.5 & 10.7 & 8.1 \\
\hline Vaux's Swift & 0.34 & 1.29 & 1.5 & 2.1 & 1.8 \\
\hline Warbling Vireo & 0.58 & 0.70 & 3.2 & 4.5 & 3.4 \\
\hline Western Tanager & 0.37 & 1.18 & 3.7 & 5.3 & 4.0 \\
\hline Western Wood-Pewee & 0.31 & 1.39 & 1.5 & 2.1 & 1.6 \\
\hline Wilson's Warbler & 0.20 & 1.93 & 5.2 & 7.3 & 5.6 \\
\hline Winter Wren & 0.05 & 4.02 & 17.8 & 25.1 & 19.1 \\
\hline Yellow-rumped Warbler & $<0.01$ & 9.17 & 17.1 & 24.1 & 18.3 \\
\hline
\end{tabular}

1. Smallest difference between means that was potentially detectable with $80 \%$ power.

2. Smallest difference between means that would almost certainly have been detected with $80 \%$ power.

3. Minimum difference between means that would be significant at $P \leq 0.10$.

\section{Discussion}

\section{Small Mammals}

All small mammal species were at least as abundant in both partial cut treatments as in the uncut forest, with red-backed voles substantially more abundant in the light removal treatment. The greatest change occurred in clearcuts, where meadow voles and deer mice substantially increased in abundance and red-backed voles declined in abundance. The 


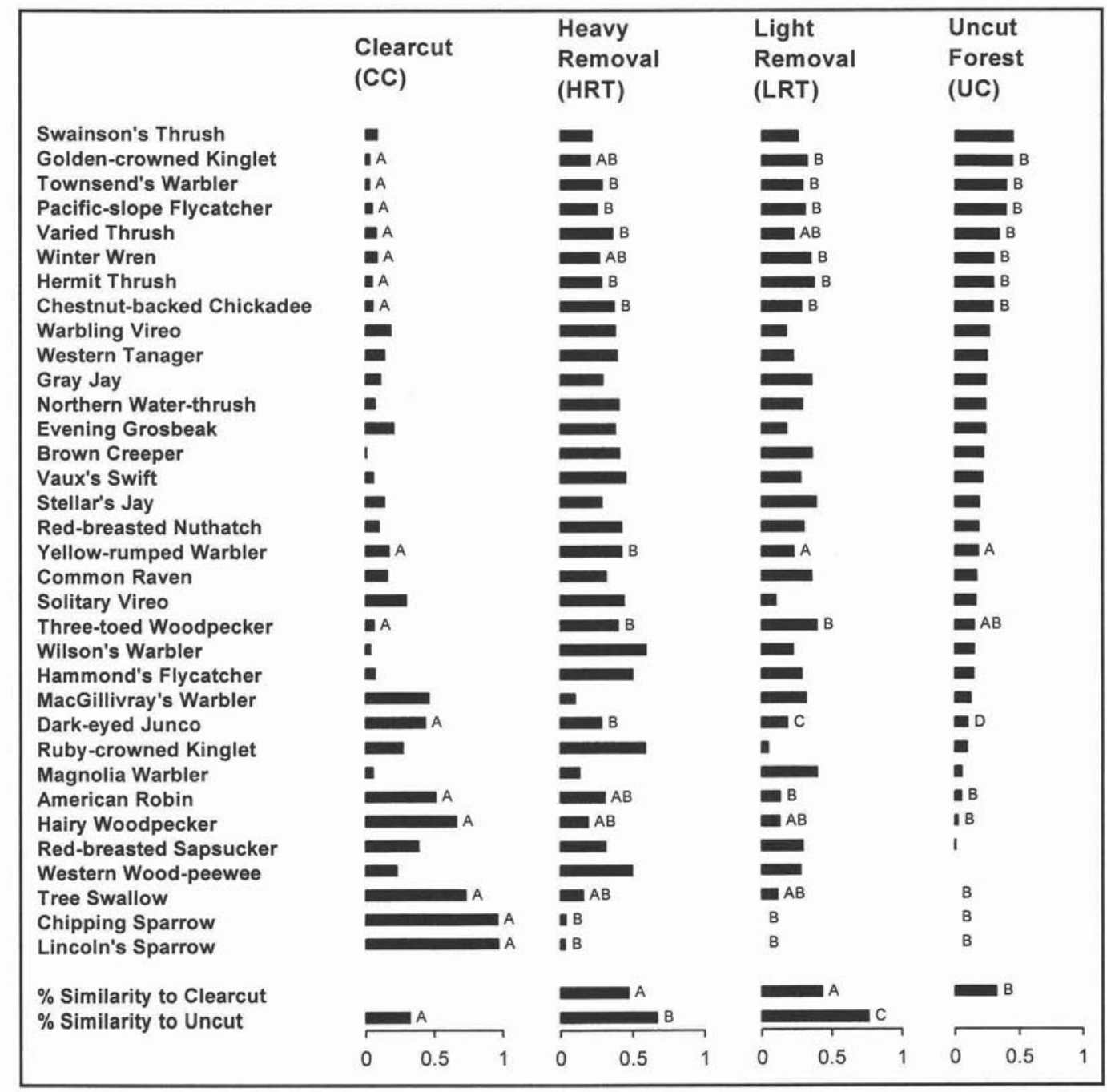

Fig. 5. Relative abundance of common bird species (averaged for both years post-treatment), and percent community similarity by treatment. Width of bar represents the proportion of detections for each species by treatment. For species with a significant treatment effect $(P \leq 0.10$, Table 3), the same letter beside a bar indicates no statistical difference between those treatments for that species (Tukey Test $P \geq 0.10$ ). Species are listed in descending order of greatest proportional abundance in the uncut treatment.

heavy removal treatment also had a greater abundance of meadow voles then either the uncut forest or light-removal treatments. Shrews appear to be generalists, occurring in similar abundance in all treatments.

Small mammal abundance alone may not fully reflect differences in habitat quality (Van Horne 1983). A habitat with higher abundance may have a lower rate of survival or reproduction then a habitat with lower abundance. Recapture rates, along with abundance, can provide better insight into habitat quality. A low recapture rate suggests low survival or a high proportion of transient animals; a condition expected in low quality habitat. A high recapture rate suggests high survival or a low proportion of transient animals; a condition expected in high quality habitat. Recapture rates in our study did not differ among treatments, or showed patterns similar to those observed for relative abundance. This suggests that treatments with high relative abundance of small mammals were higher quality habitat than those with low relative abundance.
There are few published studies of small mammal responses to partial cutting. Carey and Johnson (1995) compared small mammal communities in natural old-growth stands to managed even-aged and uneven-aged stands in western hemlock-dominated forests of the Olympic Peninsula in Washington. While small mammal abundance and productivity for most species were greatest in natural old-growth, all species were abundant in managed stands as well. Abundance of small mammals in uneven-aged managed stands tended to be intermediate between natural old-growth and young even-aged stands. Carey and Johnson (1995) suggested that coarse woody debris and understory shrub development were key variables affecting small mammal abundance, and could potentially be maintained or enhanced by partial cutting. In spruce-fir forests of northern Maine, Monthey and Soutiere (1985) reported greater abundance of southern red-backed voles and meadow voles in both partially cut stands ( $50 \%$ basal area reduction) and regenerating clearcuts than in uncut stands. Deer mouse abundance was similar in uncut, partially cut, and recently clearcut habitats. Monthey and Soutiere (1985) also associated increased 
small mammal abundance with increased understory vegetation resulting from a more open forest canopy. Clough (1987) reported similar small mammal response with reduced tree canopy closure after spruce budworm (Choristoneura fumiferana) attack or logging. Nordyke and Buskirk (1991) found southern redbacked vole populations in Wyoming were higher in old-growth spruce-fir forest with gaps than in more closed-canopy mature stands.

It appears that the creation of openings in closed-canopy conifer forest, either by natural disturbance or timber harvesting, increases small mammal abundance and diversity. With heavy canopy removals, such as with clearcut or shelterwood systems, the most dramatic response is an increase in meadow voles and a decrease in red-backed voles.

\section{Birds}

The bird community of the light-removal treatment was similar to that of the uncut forest, while the clear-cuts were distinctly different from uncut forest. The heavy-removal treatment also retained substantial abundance of most species associated with uncut forest, but was also used by some open-habitat species more typical of clearcuts. At least one species preferred the mixed conditions created by the heavy removal treatment.

For species such as the Hammond's Flycatcher, that perch in trees and hunt for flying insects in openings, preference for partial cuts was expected. In contrast, the use or possible preference for the partial-cut treatments by species that forage for insects in bark crevices of large trees (Three-toed Woodpecker, Hairy Woodpecker, Brown Creeper, and Red-breasted Nuthatch) was surprising, given the reduction in tree density. Adam et al. (1996) and Hagar et al. (1996) reported similar responses to commercial thinning in second-growth Douglas-fir (Pseudotsuga menziesii) forests. The reasons are unclear, but a relatively open stand structure appears to improve foraging opportunities for these species.

Clearcuts create early seral conditions favoured by species such as the American Robin, Lincoln's Sparrow, and Chipping Sparrow that use open habitats. As herb and shrub communities develop in the clearcuts, we expect that there will be an increasing diversity and abundance of shrub-favouring bird species.

Scattered mature trees (mostly aspen and birch) left in two of the clearcuts provided nesting sites for Red-breasted Sapsuckers, Hairy Woodpeckers and Tree Swallows. Woodpeckers used these trees for nesting, but were observed foraging in adjacent mature forest, whereas swallows both nested and foraged within the clearcuts. Several other species (e.g., Varied Thrush and Pacific-slope Flycatcher), while occasionally detected along the edges of clearcuts, were primarily using the adjacent uncut or partially cut areas. Had the clearcuts been larger with less edge relative to area, or no scattered mature trees left unharvested, we expect that the bird community similarity of the clearcuts to the other treatments would have been lower.

Hansen et al. (1995b) using bird abundance data from several studies in the U.S. Pacific Northwest, suggested that most forest birds can be placed in four guilds in terms of overstory tree canopy density: open canopy species (e.g., Dark-eyed Junco and American Robin); open canopy with dispersed large trees (e.g., MacGillivray's Warbler, Hammond's
Flycatcher, and Western Tanager); structurally complex closed-canopy (e.g., Brown Creeper, Chestnut-backed Chickadee and Winter Wren); and structurally simple closedcanopy species (e.g., Golden-crowned Kinglet and Swainson's Thrush). Our results, and those of Mannan and Meslow (1984), Adam et al. (1996), and Hagar et al. (1996) in the northwestern U.S.A., and Annand and Thompson (1997) in hardwood forests of Missouri, supported that conceptualization. By varying the intensity and spatial pattern (dispersed or clumped) of timber harvest within a stand, forest managers can create the range of conditions favoured by the different guilds.

Our study only examined relative abundance of birds. While difficult to conduct, further studies of nesting success and productivity of selected species under varying partial cutting regimes are needed to fully assess habitat quality and the resulting population implications (Donovan et al. 1995). Suarez et al. (1997), for example, reported that the nesting success rate for Indigo Buntings (Passerina cyanea) in artificial openings $(<1.0$ ha) created by partial cutting was similar to that in natural tree-fall gaps in hardwood forests of southern Illinois. However, two other species reportedly had higher nest predation rates in partially-cut areas as compared to natural forests (S. Robinson and W.D. Robinson, unpublished data cited in Suarez et al. [1997]).

\section{Application and Limitations of Partial Cutting}

Our results suggest that partial cutting has less effect on the abundance of mature-forest-dwelling birds and small mammals than would an equivalent tree volume removed using clearcutting. The LRT had minimal detrimental short-term effects despite removal of about $30 \%$ of the timber volume. The bird and small mammal communities of the HRT, while clearly changed after logging, were still more similar to the uncut forest than to the clearcuts. Habitat for some species was apparently enhanced by partial cutting, compared to either the uncut forest or clearcuts.

While the primary focus of conservation efforts is on mature and old-growth forest, the early seral conditions created by clearcuts is also an important habitat within a landscape. The value of clearcuts to some bird species can be enhanced by simply leaving scattered individual mature trees or patches of trees.

There are important potential limitations to our study, and to partial cutting in general. At Date Creek, the partial-cutting treatments were a first entry into natural stands that were not previously exploited except for a minor amount of cedar removal 40 years earlier. Through time, with repeated harvest entries, the stands can be expected to be converted increasingly to vigorous crop trees, with a long term decline in abundance of snags, downed logs, and tree size diversity (Gore and Patterson 1986, McComb et al. 1993, Buongiorno et al. 1994, Sammuelsson et al. 1994, Bader et al. 1995). The magnitude of these changes will depend upon the frequency of harvest and intensity of harvest entry. Setting management objectives for these structural features will be crucial to maintaining habitat values.

We did not attempt to examine winter habitat use because of the limited size of our treatment units and the low density of most wintering birds and small mammals. Our treatment units were also too small for study of low density or wide-ranging species such as owls or marten (Martes americana). The 
suitability of the treatments for these species requires testing at a larger spatial scale. Even some of the birds that we report on in this study, namely the woodpeckers, were observed nesting in one treatment but foraged in another. The general abundance and proximity of uncut forest within the study area may also have influenced the use of the other treatments by some species. For example, as unmanaged mature forest declines in abundance, associated species may be forced to use sub-optimal habitat.

Despite the limitations, we believe the evidence supports using partial cutting to help achieve both timber production and wildlife conservation goals for some species. Given that no single prescription for canopy retention is optimal for all species, we support the approach suggested by Bradshaw (1992), McComb et al. (1993), Bunnell and Galindo-Leal (1995), and the Clayoquot Scientific Panel (1995), who suggested creating a variety of habitat conditions by using silvicultural treatments that approximate the range of natural disturbance intensity. For forests in our study area, harvest intensity could vary from low rates of mature tree retention (1-10\%) simulating severe wildfire, through treatments similar to our HRT or LRT simulating windthrow or other gap-creating disturbances. Unmanaged stands of various ages are also needed as ecological bench-marks, and as habitat for other taxa that may not find managed stands suitable (Berg et al. 1995). The appropriate mix of treatments will vary with the conservation and economic objectives of a particular landscape.

\section{Acknowledgements}

This project was primarily funded by the Alternative Silviculture Systems research initiative of the BC Ministry of Forests under the BC/Canada Forest Resources Development Agreement. The Kispiox Forest District administered the timber harvesting, and assisted in many ways. D. Coates, P. LePage and A. Banner devised the overall experimental design and treatments. Field assistants included M. Force, C. Wong, J. Lemieux, D. Patterson, S. Mitchell, L. Mahon, J. Jones and L. Hartford. V. Sit and W. Bergerud provided valuable statistical advice. J. Pojar and K.D. Coates provided helpful reviews of earlier drafts. Thorough review by two anonymous referees and the Associate Editor greatly improved the manuscript.

\section{References}

Adam, M., J.P. Hayes, and J. Weeks. 1996. Effects of commercial thinning on bird abundance and diversity in the Oregon Coast Range: a preliminary report. Coastal Oregon Productivity Enhancement Program. Vol. 9: 4-6.

Annand, E.M. and F.R. Thompson. 1997. Forest bird response to regeneration practices in central hardwood forests. J. Wildl. Manage. 61: 159-171.

Bader, P., S. Jansson, and B.G. Jonsson. 1995. Wood-inhabiting fungi and substratum decline in selectively logged boreal spruce forests. Biol. Conserv. 72: 335-362.

Berg, A., B. Ehnstrom, L. Gustafsson, T. Hallingback, M. Jonsell, and J. Weslien. 1995. Threat levels and threats to red-listed species in Swedish forests. Conserv. Biol. 9: 1629-1633.

Bergerud, W. 1995. Post-hoc power analysis for ANOVA F-tests. Biometric Information Pamphlet \#52, B.C. Min. For., Res. Br., Victoria, B.C.

Bradshaw, F.J. 1992. Quantifying edge effect and patch size for multiple-use silviculture - a discussion paper. For. Ecol. and Manage. 48: 249-262.
Bunnell, F.L. and C. Galindo-Leal. 1995. Ecosystem management: implications and opportunities of a new paradigm. For. Chron. 71: 601-606.

Buongiorno, J., S. Dahir, H. Lu, C. Lin. 1994. Tree size diversity and economic returns in uneven-aged forest stands. For. Sci. 40: 83-103.

Carey, A.B. and M.L. Johnson. 1995. Small mammals in managed, naturally young, and old-growth forests. Ecol. Appl. 5: 336-352. Clayoquot Scientific Panel for Sustainable Forest Practices in Clayoquot Sound. 1995. Sustainable ecosystem management in Clayoquot Sound: Planning and practices. Secretariat, Cortex Consultants Inc., Victoria, B.C.

Clough, G.C. 1987. Relations of small mammals to forest management in northern Maine. Can. Field-Nat. 101: 40-48.

Coates, K.D. and J.D. Steventon. 1995. Patch retention as a technique for maintaining stand level biodiversity in forests of north central British Columbia. In C.R. Bamset (ed.). Innovative silviculture systems in boreal forests, Symposium Proceedings. pp. 102-106. Clear Lake Limited, Edmonton, Alta.

Coates, K.D., A. Banner, J.D. Steventon, P. LePage, and P. Bartemucci. 1997. The Date Creek silvicultural systems study in the Interior Cedar-Hemlock forests of northwestern British Columbia: overview and treatment summaries. B.C. Min. For., Res. Br., Victoria, B.C., Land Management Handbook No. 38.

Donovan, T.M., F.R. Thompson, III, J. Faaborg, and J.R. Probst. 1995. Reproductive success of migratory birds in habitat sources and sinks. Conserv. Biol. 9: 1380-1395.

Gore, J.A. and W.A. Patterson III. 1986. Mass of downed wood in northern hardwood forests in New Hampshire: potential effects of forest management. Can. J. For. Res. 16: 335-339.

Government of BC. 1994. Forest, range and recreation resource analysis. B.C. Min. For., Victoria, B.C.

Government of BC. 1995a. Silvicultural systems guidebook. B.C. Min. For. and B.C. Ministry of Environment, Lands, and Parks, Victoria B.C.

Government of BC. 1995b. Biodiversity guidebook. B.C. Min. For. and B.C. Ministry of Environment, Lands, and Parks, Victoria B.C. Hagar, J.C., William C. McComb, and William H. Emmingham. 1996. Bird communities in commercially thinned and unthinned Douglasfir stands of western Oregon. Wildl. Soc. Bull. 24: 353-366.

Hansen, A.J., S.L.Garman, J.F. Weigand, D.L. Urban, W.C. McComb, and M.G. Raphael. 1995a. Alternative silvicultural regimes in the Pacific Northwest: simulations of ecological and economic effects. Ecol. Appl. 5: 535-554.

Hansen, A.J., W.C. McComb, R. Vega, M.G. Raphael and M. Hunter. 1995b. Bird habitat relationships in natural and managed forests in the west cascades of Oregon. Ecol. Appl. 5: 555-569.

Harmon, M.E., J.F. Franklin, F.J. Swanson, P. Sollins, S.V. Gregory, J.D. Lattin, N.H. Anderson, S.P. Cline, N.G. Aumen, J.R. Sedell, G.W. Lienkaemper, K. Cromack, Jr., and K.W. Cummins. 1986. Ecology of coarse woody debris in temperate ecosystems. Adv. Ecol. Res. 15: 133-302.

Hunter, M.L. 1990. Wildlife, forests, and forestry: principles of managing forests for biological diversity. Prentice Hall, Englewood Cliffs, N.J. 370 p.

Krebs, C.J. 1989. Ecological methodology. Harper and Row Publishers Inc., New York, N.Y. 654 p.

LePage, P. 1995. The structure and development pattern of mixedspecies forest stands in the Interior Cedar-Hemlock zone; Moist Cold Subzone of northwestern British Columbia. M.Sc. Thesis. Oregon State Univ., Corvalis, OR, 91 p.

Mannan, R.W. and E.C. Meslow. 1984. Bird populations and vegetation characteristics in managed and old-growth forests, northeastern Oregon. J. Wildl. Manage. 48: 1219-1238.

McComb, W. C., T.A. Spies, and W.H. Emmingham. 1993. Douglas-fir forests. Managing for timber and mature-forest habitat. J. For. 91: 31-42. 
Meidinger, D. and J. Pojar. 1991. Ecosystems of British Columbia. Special Rep. \#6, B.C. Min. For., Victoria, B.C.

Monthey, R.W. and E.C. Soutiere. 1985. Responses of small mammals to forest harvesting in northern Maine. Can. Field-Nat. 99:13-18.

Nordyke, K.A. and S.W. Buskirk. 1991. Southern red-backed vole, Clethrionomys gapperi, populations in relation to stand succession and old-growth character in the central Rocky Mountains. Can. Field-Nat. 105: 330-334.

Renkonen, O. 1938. Statisch-okologishe untersuch-ungen uber die terrestiche kaferwelt der Finnischen bruchmore. Ann. Zool. Soc. Bot. Fenn. Vanamo 6: 1-123.

Samuelsson, J., L. Gustafsson, and T. Ingelog. 1994. Dying and dead trees. a review of their importance for biodiversity. Swedish Environmental Protection Agency, Uppsala Sweden. 109pp.

Spies, T.A., J. Tappeiner, J. Pojar, and D. Coates. 1991. Trends in ecosystem management at the stand level. Trans. 56th N.A. Wildl. Nat. Res. Conf. Pp. 628-639.

Suarez, A.V., K. S. Pfennig, and S. K. Robinson. 1997. Nesting success of a disturbance-dependent songbird on different kinds of edges. Conserv. Biol. 11: 928-935.
Thibodeau, E.D., R.K. Krag, and I.B. Hedin. 1996. The Date Creek study: productivity of ground-based harvesting methods in the Interior Cedar-Hemlock zone of British Columbia. Forest Engineering Research Institute of Canada, Western Division, 2601 East Mall, Vancouver, B.C. Special Report No. SR-114.

Thompson, F.R., J.R. Probst, and M.G. Raphael. 1993. Silvicultural options for neotropical migratory birds. In D. Finch and P. Stangel (eds.). Status and management of neotropical birds. pp. 353-362. USDA For. Ser. Gen. Tech. Rep. RM-229. Rocky Mountain Forest and Range Experiment Station, Fort Collins, Co.

Van Horne, B. 1983. Density as a misleading indicator of habitat quality. J. Wildl. Manage. 47: 893-901.

Van Wagner, C.E. 1982. Practical aspects of the line intercept method. Forestry Canada Information Report PI-X-12. 11 pp.

Weetman, G.F., E. Panozzo, M. Jull, and K. Marek. 1990. An assessment of opportunities for alternative silvicultural systems in the SBS, ICH, and ESSF biogeoclimatic zones of the Prince Rupert Forest Region. Report to B.C. Ministry of Forests, Prince Rupert Forest Region, Smithers, B.C. 154 pp.

Appendix 1

Scientific names and number of post-treatment detections/ 20 ha by treatment $(n=4)$ for all bird species detected, averaged for 1993 and 1994.

\begin{tabular}{|c|c|c|c|c|c|c|c|c|c|}
\hline \multirow{2}{*}{ Species } & & \multicolumn{2}{|c|}{ Clearcut } & \multicolumn{2}{|c|}{ Heavy Removal } & \multicolumn{2}{|c|}{ Light Removal } & \multicolumn{2}{|c|}{ Uncut } \\
\hline & & mean & SE & mean & SE & mean & SE & mean & SE \\
\hline American Kestrel & Falco sparverius & 0.40 & 0.25 & 0.10 & 0.10 & 0.00 & 0.00 & 0.09 & 0.09 \\
\hline American Pipit & Anthus spinoletta & 1.07 & 0.86 & 0.21 & 0.12 & 0.47 & 0.47 & 0.21 & 0.21 \\
\hline American Redstart & Setophaga ruticilla & 0.00 & 0.00 & 0.00 & 0.00 & 0.22 & 0.13 & 0.00 & 0.00 \\
\hline American Robin & Turdus migratorius & 18.63 & 6.79 & 11.22 & 4.45 & 4.80 & 1.81 & 1.88 & 0.69 \\
\hline Barred Owl & Strix varia & 0.00 & 0.00 & 0.00 & 0.00 & 0.00 & 0.00 & 0.52 & 0.30 \\
\hline Belted Kingfisher & Megaceryle alcyon & 0.30 & 0.20 & 0.00 & 0.00 & 0.00 & 0.00 & 0.09 & 0.09 \\
\hline Black-capped Chickadee & Parus atricapillus & 0.00 & 0.00 & 0.22 & 0.13 & 0.36 & 0.12 & 0.47 & 0.27 \\
\hline Blackpoll Warbler & Dendroica striata & 0.00 & 0.00 & 0.10 & 0.10 & 0.00 & 0.00 & 0.00 & 0.00 \\
\hline Brown Creeper & Certhia americana & 0.08 & 0.08 & 5.96 & 2.76 & 5.25 & 1.80 & 3.26 & 0.63 \\
\hline Calliope Hummingbird & Stellula calliope & 0.00 & 0.00 & 0.00 & 0.00 & 0.11 & 0.11 & 0.00 & 0.00 \\
\hline Canada Goose & Branta canadensis & 0.00 & 0.00 & 0.10 & 0.10 & 0.00 & 0.00 & 0.00 & 0.00 \\
\hline Chestnut-backed Chickadee & Parus rufescens & 5.03 & 1.62 & 35.67 & 3.29 & 27.09 & 3.72 & 28.19 & 1.91 \\
\hline Chipping Sparrow & Spizella passerina & 2.78 & 1.03 & 0.11 & 0.11 & 0.00 & 0.00 & 0.00 & 0.00 \\
\hline Common Loon & Gavia immer & 0.08 & 0.08 & 0.00 & 0.00 & 0.12 & 0.12 & 0.00 & 0.00 \\
\hline Common Raven & Corvus corax & 0.41 & 0.25 & 0.83 & 0.15 & 0.93 & 0.32 & 0.44 & 0.16 \\
\hline Common Snipe & Gallinago gallinago & 0.32 & 0.18 & 0.00 & 0.00 & 0.00 & 0.00 & 0.09 & 0.09 \\
\hline Dark-eyed Junco & Junco hyemalis & 88.01 & 2.33 & 57.12 & 5.44 & 37.39 & 2.21 & 19.99 & 3.75 \\
\hline Dusky Flycatcher & Empidonax oberholseri & 0.00 & 0.00 & 0.00 & 0.00 & 0.00 & 0.00 & 0.12 & 0.12 \\
\hline Evening Grosbeak & Hesperiphona vespertina & 1.28 & 0.76 & 2.36 & 0.80 & 1.10 & 0.43 & 1.47 & 0.46 \\
\hline Golden-crowned Kinglet & Regulus satrapa & 1.41 & 0.82 & 10.32 & 3.35 & 16.05 & 3.10 & 22.20 & 6.86 \\
\hline Gray Jay & Perisoreus canadensis & 0.61 & 0.28 & 1.64 & 0.93 & 1.98 & 0.63 & 1.35 & 0.79 \\
\hline Greater Yellowlegs & Tringa melanoleuca & 1.52 & 1.52 & 0.00 & 0.00 & 0.00 & 0.00 & 0.00 & 0.00 \\
\hline Hairy Woodpecker & Picoides villosus & 6.07 & 2.76 & 1.76 & 0.49 & 1.16 & 0.40 & 0.21 & 0.12 \\
\hline Hammond's Flycatcher & Empidonax hammondii & 2.68 & 1.20 & 19.63 & 10.19 & 11.11 & 7.89 & 5.75 & 2.76 \\
\hline Hermit Thrush & Catharus guttatus & 1.94 & 0.71 & 11.79 & 0.93 & 15.46 & 3.94 & 12.41 & 2.57 \\
\hline Lincoln's Sparrow & Melospiza lincolnii & 3.36 & 1.88 & 0.11 & 0.11 & 0.00 & 0.00 & 0.00 & 0.00 \\
\hline Magnolia Warbler & Dendroica magnolia & 0.69 & 0.42 & 0.65 & 0.53 & 0.22 & 0.13 & 0.09 & 0.09 \\
\hline Mallard & Anas platyrhynchos & 0.45 & 0.35 & 0.00 & 0.00 & 0.00 & 0.00 & 0.00 & 0.00 \\
\hline MacGillivray's Warbler & Oporornis tolmiei & 1.53 & 1.04 & 0.34 & 0.22 & 1.05 & 1.05 & 0.40 & 0.27 \\
\hline Merlin & Falco columbarius & 0.08 & 0.08 & 0.00 & 0.00 & 0.00 & 0.00 & 0.00 & 0.00 \\
\hline Northern Flicker & Colaptes auratus & 0.24 & 0.24 & 0.10 & 0.10 & 0.24 & 0.14 & 0.21 & 0.12 \\
\hline Northern Goshawk & Accipiter gentilis & 0.00 & 0.00 & 0.21 & 0.12 & 0.00 & 0.00 & 0.00 & 0.00 \\
\hline \multicolumn{10}{|l|}{ Northern Rough-winged } \\
\hline Swallow & Stelgidopteryx serripennis & 0.38 & 0.24 & 0.10 & 0.10 & 0.22 & 0.13 & 0.00 & 0.00 \\
\hline Northern Waterthrush & Seiurus noveboracensis & 0.22 & 0.22 & 1.31 & 1.18 & 0.93 & 0.93 & 0.77 & 0.64 \\
\hline Olive-sided Flycatcher & Contopus borealis & 0.08 & 0.08 & 0.62 & 0.25 & 0.36 & 0.21 & 0.00 & 0.00 \\
\hline Orange-crowned Warbler & Vermivora celata & 0.12 & 0.12 & 0.11 & 0.11 & 0.11 & 0.11 & 0.23 & 0.23 \\
\hline Pacific-slope Flycatcher & Empidonax difficilis & 5.60 & 2.52 & 30.76 & 4.12 & 37.58 & 5.44 & 48.41 & 8.69 \\
\hline Pileated Woodpecker & Dryocopus pileatus & 0.00 & 0.00 & 0.00 & 0.00 & 0.00 & 0.00 & 0.09 & 0.09 \\
\hline Pine Grosbeak & Pinicola enucleator & 0.00 & 0.00 & 0.23 & 0.23 & 0.11 & 0.11 & 0.00 & 0.00 \\
\hline Pine Siskin & Carduelis pinus & 13.91 & 3.20 & 21.30 & 2.51 & 16.17 & 2.44 & 11.66 & 3.08 \\
\hline Purple Finch & Carpodacus purpureus & 0.00 & 0.00 & 0.32 & 0.11 & 0.15 & 0.15 & 0.00 & 0.00 \\
\hline Red-breasted Nuthatch & Sitta canadensis & 1.45 & 0.73 & 6.36 & 3.30 & 4.50 & 0.64 & 2.75 & 0.95 \\
\hline Red-breasted Sapsucker & Sphyrapicus ruber & 4.84 & 2.17 & 3.96 & 3.67 & 3.65 & 1.88 & 0.09 & 0.09 \\
\hline
\end{tabular}


Red Crossbill

Red-tailed Hawk

Red-winged Blackbird

Ring-necked Duck

Ruby-crowned Kinglet

Rufous Hummingbird

Rusty Blackbird

Savannah Sparrow

Say's Phoebe

Solitary Sandpiper

Solitary Vireo

Song Sparrow

Spruce Grouse

Stellar's Jay

Swainson's Thrush

Three-toed Woodpecker

Townsend's Solitaire

Townsend's Warbler

Tree Swallow

Varied Thrush

Vauxís Swift

Violet-green Swallow

Warbling Vireo

Western Tanager

Western Wood-Pewee

White-crowned Sparrow

White-winged Crossbill

Wilson's Warbler

Winter Wren

Yellow-rumped Warbler Yellow Warbler

\begin{tabular}{lr} 
Loxia curvirostra & 6.55 \\
Buteo jamaicensis & 0.60 \\
Agelaius phoeniceus & 0.00 \\
Aythya collaris & 0.60 \\
Regulus calendula & 0.60 \\
Selasphorus rufus & 0.51 \\
Euphagus carolinus & 0.70 \\
Passerculus sandwichensis & 0.30 \\
Sayornis saya & 0.08 \\
Tringa solitaria & 1.84 \\
Vireo solitarius & 0.67 \\
Melospiza melodia & 0.15 \\
Dendragapus canadensis & 0.00 \\
Cyanocitta stelleri & 1.58 \\
Catharus ustulatus & 1.02 \\
Picoides tridactylus & 1.08 \\
Myadestes townsendi & 0.57 \\
Dendroica townsendi & 4.58 \\
Tachycineta bicolor & 2.55 \\
Ixoreus naevia & 3.75 \\
Chaetura vauxi & 0.17 \\
Tachycineta thalassina & 0.52 \\
Vireo gilvus & 1.46 \\
Piranga ludoviciana & 1.48 \\
Contopus sordidulus & 0.56 \\
Zonotrichia leucophrys & 0.24 \\
Loxia leucoptera & 1.39 \\
Wilsonia pusilla & 0.30 \\
Troglodytes troglodytes & 7.03 \\
Dendroica coronata & 20.71 \\
Dendroica petechia & 0.00 \\
& \\
\hline
\end{tabular}

$\begin{array}{r}10.91 \\ 0.00 \\ 0.11 \\ 0.00 \\ 1.30 \\ 0.10 \\ 1.00 \\ 0.00 \\ 0.00 \\ 0.22 \\ 1.01 \\ 0.00 \\ 0.00 \\ 3.31 \\ 2.69 \\ 7.07 \\ 0.00 \\ 48.71 \\ 0.55 \\ 17.58 \\ 1.35 \\ 0.00 \\ 3.02 \\ 4.26 \\ 1.22 \\ 0.00 \\ 1.11 \\ 5.04 \\ 23.54 \\ 52.52 \\ 0.20 \\ \hline\end{array}$

1.20
0.00
0.11
0.00
0.90
0.10
0.85
0.00
0.00
0.22
0.87
0.00
0.00
2.19
0.70
1.47
0.00
12.31
0.55
3.69
0.52
0.00
1.06
1.58
0.44
0.00
0.52
2.47
6.41
7.30
0.20

1.78
0.00
0.00
0.00
0.11
0.12
0.12
0.00
0.00
0.12
0.13
0.12
0.00
1.38
1.80
1.47
0.00
6.38
0.40
1.84
0.52
0.00
1.23
1.60
0.50
0.00
0.39
1.10
6.86
5.21
0.00

8.32

0.88

$0.41 \quad 0.00$
0.00

0.00

0.00

0.41

0.19

0.59

0.20

0.08

0.15

0.60

0.25

0.43

1.96

1.18

1.82

0.17

0.41

0.98

0.83

0.41

0.24

0.48

0.20

0.00

$\begin{array}{r}8.76 \\ 0.00 \\ 0.00 \\ 0.00 \\ 0.11 \\ 0.36 \\ 0.12 \\ 0.00 \\ 0.00 \\ 0.12 \\ 0.22 \\ 0.12 \\ 0.00 \\ 4.47 \\ 3.20 \\ 6.93 \\ 0.00 \\ 49.33 \\ 0.40 \\ 10.92 \\ 0.82 \\ 0.00 \\ 1.38 \\ 2.39 \\ 0.67 \\ 0.00 \\ 1.51 \\ 1.88 \\ 30.25 \\ 28.10 \\ 0.00 \\ \hline\end{array}$

$\begin{array}{ll}0.00 & 0.00\end{array}$

$\begin{array}{ll}0.12 & 0.12\end{array}$

$0.21 \quad 0.12$

$\begin{array}{ll}0.00 & 0.00\end{array}$

$0.13 \quad 0.13$

$0.00 \quad 0.00$

$0.00 \quad 0.00$

$0.00 \quad 0.00$

$0.38 \quad 0.25$

$0.00 \quad 0.00$

$0.13 \quad 0.13$

$\begin{array}{ll}2.20 & 0.71\end{array}$

$5.60 \quad 1.94$

$\begin{array}{ll}2.67 & 0.50\end{array}$

$\begin{array}{ll}0.12 & 0.12\end{array}$

$\begin{array}{ll}68.27 & 7.70\end{array}$

$\begin{array}{ll}0.00 & 0.00\end{array}$

$16.57 \quad 5.60$

$\begin{array}{ll}0.64 & 0.38\end{array}$

$0.00 \quad 0.00$

$\begin{array}{ll}2.09 & 1.09\end{array}$

$2.71 \quad 1.27$

$0.00 \quad 0.00$

$0.00 \quad 0.00$

$\begin{array}{ll}1.19 & 0.13\end{array}$

$\begin{array}{ll}1.26 & 0.49\end{array}$

$\begin{array}{rr}1.26 & 0.46 \\ 25.27\end{array}$

$22.37-1.41$

$0.00 \quad 0.00$

